\section{Lembaran Sejarah}

\title{
Dangdut dan Rezim Orde Baru: Wacana Nasionalisasi Musik Dangdut Tahun 1990-an
}

\section{DERTA ARJAYA}

Universitas Gadjah Mada

\begin{abstract}
This research tries to answer two main questions. First, what was the reason for the nationalization of dangdut in 1990s period. Second, how was the discourse taken place and who benefited from the nationalization of the popular music. History method is applied in this research, by using sources, such as, magazines, newspapers, books, scientific works, which are spread in several places. The main inventions of this research are, firstly, the nationalization of dangdut was strongly related to the development of dangdut in the 1970's to 1990's periods. Secondly, the strategy of the regime to nationalize dangdut in the middle 1990s was conducted through supporting the development of positive dangdut. Third, the nationatization of dangdut in the 1990s benefited both the New Order regime and dangdut itself.
\end{abstract}

\begin{abstract}
Abstrak
Tulisan ini hendak menjawab dua pertanyaan pokok; Pertama, apa yang melatar belakangi wacana nasionalisasi terhadap musik dangdut pada 1990-an. Kedua, bagaimana wacana tersebut digulirkan dan siapa yang diutungkan dari wacana tersebut. Metode Sejarah digunakan dalam tulisan ini dengan menggunakan sumber-sumber seperti majalah, koran, buku dan artikel yang tersebar diberbagai tempat. Temuan utama penelitian ini adalah; Pertama, ternyata wacana yang digulirkan rezim Orba untuk menjadikan musik dangdut sebagai musik nasional Indonesia tidak terlepas dari perkembangan musik dangdut yang sangat luar biasa dalam periode 1970'an hingga 1990'an. Kedua, cara yang ditempuh oleh rezim Orde dalam mewacanakan dangdut sebagai musik nasional Indonesia pada pertengahan 1990-an diawali dengan pemberian dukungan terhadap perkembangan musik dangdut dan sejumlah pelarangan terhadap lagu-lagu dangdut yang dianggap memiliki unsur negatif, seperti pornografi. Ketiga, bergulirnya wacana untuk menjadikan dangdut sebagai musik nasional Indonesia pada dekade 90'an ternyata sangat menguntungkan baik bagi musisi dan musik dangdut maupun bagi rezim Orde Baru.
\end{abstract}

Keywords: dangdut; regime; nationalization

Kata kunci: dangdut; rezim; nasionalisasi 


\section{Pengantar}

"Negara ini dari rakyat, oleh rakyat dan untuk rakyat. Begitu juga dangdut, dari rakyat, oleh rakyat dan untuk rakyat." (Browne, 2000: 6)

Kutipan di atas merupakan salah satu pernyataan Menteri Sekeretaris Negara Moerdiono dalam acara peringatan HUT RI yang ke-50 di tahun 1995. Pernyataan tersebut memperlihatkan upaya rezim Orde Baru (Orde Baru) dalam mengasosiasikan dangdut dengan entitas ke-Indonesia-an. Rezim Orde Baru pada era 1990-an telah menjadikan musik dangdut sebagai "anak emas"-nya.

Perkembangan musik dangdut yang sangat pesat pada era 1970-an hingga 1990-an memunculkan beberapa dampak baik kultural maupun politis. Selain menyebabkan musik dangdut diasosiasikan sebagai musik nasional Indonesia dan "anak emas" Orde Baru (1990-an), juga telah membuat genre musik ini bergesekan dengan kepentingan rezim. Pergesekan tersebut tidak terlepas dari kenyataan bahwa lirik-lirik lagu dangdut, khususnya lagu-lagu Rhoma Irama, banyak yang menyampaikan kritisi terhadap negara. Periode pergesekan tersebut berlangsung pada 1970-an hingga 1980-an.

Pergesekan antara musik dangdut dan kepentingan rezim Orde Baru secara umum dapat dikatakan berakhir ketika memasuki periode 1990-an. Pada periode ini musik dangdut justru terlihat sangat dekat dengan rezim. Fenomena semacam ini tampaknya dapat digambarkan melalui konsep Nirwan Dewanto mengenai bagaimana proses persinggungan antara seni dan politik. Ia mengatakan bahwa:

"Tidak ada seni tanpa publik. Dan pada gilirannya, jika publik itu telah mencapai jumlah yang signifikan, keindahan (dan kebenaran) seni akan memperlihatkan sisinya yang lain, yakni sisi etis. Di sinilah seni mulai bersinggungan dengan kekuasaan." (Dewanto, 1996: 13)

Musik dangdut, sebagaimana yang telah diuraikan dalam paragraf di atas, dalam perkembangannya juga tidak terlepas dari pergesekan dengan kepentingan rezim. Namun demikian, pergesekan tersebut perlahan menjadi hubungan yang saling menguntungkan. Periode ini berlangsung selama 1990-an, saat di mana rezim Orde Baru mulai menggulirkan wacana untuk menjadikan musik dangdut sebagai musik nasional Indonesia. Perubahan pola hubungan tersebut ternyata mendatangkan keuntungan yang luar biasa besar, baik bagi rezim maupun musik dangdut.

Tulisan ini hendak menjawab dua pertanyaan. Pertama, apa yang melatarbelakangi wacana nasionalisasi terhadap musik dangdut pada 1990an? Kedua, bagaimana wacana tersebut digulirkan dan siapa yang diutungkan dari wacana tersebut? 


\section{Perkembangan Musik Dangdut 1970-an-1900-an}

Sejak kemunculannya awal tahun 1970-an, musik dangdut tengah berkembang dengan pesat. Hal tersebut dapat dilihat dari beberapa indikator seperti konser-konser, penjualan kaset dan jumlah penggemar musik dangdut.

Dilihat dari konser-konser dangdut yang diadakan selama periode 1970-an hingga 1990-an, baik di dalam maupun luar negeri, terlihat jelas bahwa perkembangan musik dangdut dalam periode tersebut luar biasa pesatnya. Rita Sugiarto bersama Rhoma Irama misalnya, pernah mengadakan konser di Manila, Timur Tengah, Tokyo dan Melbourn. Menurut Rita, di Jepang bahkan dangdut sangat digemari. ${ }^{1}$ Selain itu, Camelia Malik dan Reynold Panggebean bersama grup dangdut mereka, Tarantula, juga berhasil memperluas musik dangdut ke negara Malaysia dengan mengadakan konser pada 24-25 Desember 1986. Demikian juga dengan raja dangdut Rhoma Irama, sejak tahun 1980 sebenarnya ia sudah diundang untuk tampil di Jepang, namun karena banyaknya jadwal show, ia bersama grupnya baru dapat tampil di sana tahun 1992.

Dilihat dari penjualan kaset-kaset dangdut, terlihat jelas bahwa pada periode 1970-an hingga 1990-an, perkembangan musik dangdut sangat pesat. Majalah Tempo bahkan menyebut tahun 1979 sebagai tahun dangdut, alasannya karena dangdut pada tahun tersebut sangat mengusai pasaran kaset. Di tahun ini pula, pita-pita kaset dangdut didominasi oleh suara Rhoma Irama dan Elvy Sukaesih. Musik dangdut terdengar di mana-mana, baik di TVRI, film, pesta-pesta, mobil-mobil, bahkan sampai ke tempattempat hiburan orang-orang elite, diskotik dan klab malam. Produser juga sibuk mendangdutkan hampir semua jenis lagu pop waktu itu, penyanyi yang cilik seperti Bing Slamet dan Chica pun diharuskan menyanyikan lagulagu dangdut.

Leo Kusuma yang pada tahun 1979 menjabat sebagai Presiden Direktur Yukawi dan sekaligus ketua ASIRI (Asosiasi Industri Rekaman Indonesia) menyebutkan bahwa di Indonesia produksi kaset kosong setiap tahunnya kurang lebih sekitar enam juta buah, dua juta diantaranya digunakan oleh ASIRI untuk merekam lagu-lagu Indonesia. Sementara satu juta lagi dipakai oleh perusahaan rekaman seperti Perina dan atau AR untuk merekam lagulagu barat, sisanya (tiga juta kaset), dibeli oleh pembajak untuk menduplikat

1) Rita Sugiarto merupakan salah satu penyanyi dangdut berbakat generasi awal yang masih sangat eksis sampai saat ini. Sampai saat inipun ia masih sibuk menjadi juri dalam beberapa audisi dangdut seperti The Terong Show, Dangdut Akademi 1 dan 2. Kemunculannya sebagai penyanyi dangdut hampir bersamaan dengan munculnya istilah dangdut itu sendiri (awal 1970-an). Tahun 1976 ia bergabung dengan Soneta Grup pimpinan Rhoma Irama. Sayanyanya ia lupa tahun berapa ia manggung bersama Rhoma di luar negeri tersebut. Meskipun demikian, dapat diperkirakan sebelum awal tahun 1980-an, karena tahun 1983, ia memisahkan diri dari Soneta Grup. 
lagu-lagu dangdut yang kemudian dipasarkan ke daerah Jawa Tengah dan Jawa Timur. Eddy Sud, seorang koordinator dalam acara Musik Safarisebuah hiburan di TVRI yang waktu itu paling terkenal-dalam Kompas tanggal 5 Mei 1991 mengatakan bahwa paling tidak sejak tahun 1991, sulit menemukan produser kaset yang tidak memproduksi lagu-lagu dangdut.

Selanjutnya, dilihat dari sisi jangkauan maupun jumlah penggemarnya, terlihat pula bahwa perkembangan dangdut dalam periode 1970-an hingga 1990-an sangat luar biasa. Sejak pertengahan 1980-an musik dangdut telah mencapai tempat nongkrong orang-orang kelas menengah atas seperti diskotek. ${ }^{2}$ Tahun 1981 misalnya, Rhoma Irama bersama anggota Soneta grupnya beserta sejumlah penyanyi dangdut lainnya seperti Rita Sugiarto dan Elvy Sukaesih diundang pada Festival Lagu Populer ASEAN, ketika itu musik dangdut bahkan diwacanakan untuk dijadikan musik negara-negara ASEAN. ${ }^{3}$

Beberapa sumber koran dan majalah, ditambah tulisan Syamsudin Haesy (1995) menyebutkan pada tahun 1990-an popularitas dangdut telah mencapai Jepang, Turki, Australia, Malaysia, Singapura, Brunei Darusalam dan Amerika. Bahkan pada 1990-an, pengusaha Jepang pernah merilis sekitar 200 lagu Rhoma Irama untuk diedarkan di Jepang, sayangnya di dalam sumber artikel majalah tersebut tidak disebutkan namanya.

Dilihat dari ketiga indikator di atas, dapat dikatakan bahwa perkembangan musik dangdut pada periode 70 -an hingga 90 -an sangat luar biasa pesat. Perkembangan musik dangdut yang luar biasa pesat tersebut jelas mendatangkan dampak 'positif' maupun 'negatif. Dari sisi ekonomiakan dijelaskan pada bagian selanjutnya-jelas perkembangan tersebut mendatangkan keuntungan yang luar biasa bagi pihak-pihak yang terlibat di dalamnya. Namun lebih dari itu, perkembangan musik dangdut yang begitu pesat ternyata juga mengakibatkan musik dangdut bergesekan dengan kepentingan rezim Orde Baru.

\section{Mewacanakan Dangdut sebagai Musik Nasional}

Sejak awal tahun 90-an, sikap rezim Orde Baru terhadap musik dangdut sangat berbeda dengan periode-periode sebelumnya. ${ }^{4}$ Rezim Orde Baru pada

2) Hal ini terilustrasikan pada sejumlah artikel koran dan majalah seperti "Arus Baru dalam Hiburan Malam, Dangdut Menggoyang Diskotek”, Kompas, Minggu 21 Januari 1990, hlm. 1; Bunga Surawijaya, "Di Jepang Dangdut Dibayar Mahal”, Tempo, 25 Mei 1991, hlm. 59.

3) Jack Joetabarat "Sekitar Festival Lagu Populer ASEAN: Lagu dan Penyanyi Kita yang Memalukan”, Aktuil, No. 20 Tahun XIII, 3 Agustus 1981, hlm. 34. Terlepas dari komentar negatif terkait kualitas musik dangdut yang ditampilkan dalam acara tersebut yang dilontarkan oleh penulis Aktuil, tampilnya musik dangdut dalam acara festival tersebut serta diwacanakannya dangdut untuk dijadikan musik negara-negara ASEAN, memperlihatkan perkembangan genre musik ini sangat luar biasa ketika itu.

4) Sejak pertengahan 1970-an rezim Orde Baru cenderung menghambat perkembangan 
dekade 1990-an, bahkan mewacanakan untuk menjadikan dangdut sebagai musik nasional Indonesia. Pewacanaan tersebut diawali dengan pemberian dukungan yang luar biasa bagi perkembangan genre musik ini. Dukungan rezim Orde Baru terhadap perkembangan musik dangdut tampak dengan dilibatkannya musik dangdut dalam acara-acara kenegaraan. Dukungan yang tinggi dari rezim Orde Baru terhadap perkembangan musik dangdut yang pada akhirnya membuat hubungan keduanya sangat harmonis, sekaligus menandai babak baru dalam sejarah perkembangan musik dangdut.

Dukungan rezim Orde Baru terhadap perkembangan dangdut secara terang-terangan, pertamakali terlihat pada upaya pemerintah dalam memulihkan hubungan dengan Republik Rakyat Tiongkok pada November 1991. Pemerintah melalui Tim Kesenian Nusantara TMII mengirimkan rombongan musik dangdut ke Beijing, Hangzhou. Di samping itu, rombongan yang dikirim pemerintah juga tampil di Guangzhou, tepatnya di Guangzhou Art Centre dengan menampilkan salah satu lagu dangdut "Sekedar Bertanya" yang langsung membuat penonton ikut bergoyang.

Masih di tahun yang sama, dukungan rezim Orde Baru terhadap perkembangan musik dangdut kembali nampak pada malam Minggu 29 Desember 1991. Ketika itu, diselenggarakan acara peringatan HUT Kodam Jaya yang ke-42 dengan tema "Yellow Dynamic Dangdut Fiesta". Sepanjang sejarah pertunjukkan dangdut (sampai dengan tahun 1991), pertunjukan tersebut adalah yang terbesar dengan jumlah penonton lebih dari 200.000 orang. Sejumlah penyanyi dangdut papan atas yang tampil dalam acara tersebut di antaranya Camelia Malik, Rita Sugiarto, Masyur S, Megi Z, Ona Sutra, Veti Vera, Jhoni Iskandar, Latif Khan, Mega Mustika, Herlina Efendi, Yusnia, Evi Tamala, Hamdan ATT, Dani Albar dan tentu saja Rhoma Irama, sang raja dangdut yang sekaligus mendominasi pertunjukkan tersebut.

TVRI sebagai televisi negara juga memperlihatkan dukungan tersebut. Pada acara Album Minggu di TVRI tahun 1992 sebanyak 92 persen lagu yang ditayangkan ialah lagu dangdut, meskipun dalam ketentuannya acara tersebut diperuntukan bagi berbagai macam genre musik. Menurut catatan Kompas tanggal 11 Desember 1992, secara umum tahun 1990-an acara musik dangdut di TVRI berkisar antara 40 sampai 60 persen, sebuah angka yang sangat tinggi.

Selain acara di TVRI, kegemaran sejumlah pejabat tinggi rezim Orde

musik dangdut secara umum dengan dikeluarkannya larangan terhadap genre musik ini untuk tampil di TVRI. Demikian halnya tahun 1980-an, meskipun rezim Orde Baru mulai melunakan sikapnya terhadap musik dangdut, namun sejumlah larangan terhadap musisi dan musik dangdut untuk tampil di TVRI masih sering terjadi seperti lagu "Rupiah", "Hak Asasi”, “Ada Udang di Balik Batu”, dan "Capek”. Terkait pelarangan dangdut tampil di TVRI, dapat dilihat pada S.N. Ratmana, "Lagu-lagu Pop sebagai Saluran untuk Melihat Aspirasi Masyarakat: Perlu Penyaringan, tapi juga Pendekatan Lapang Dada” Kompas, 12 Oktober 1976, hlm. 5; "Lagu Rupiah akan Dilarang di Teve", Kompas, 21 September 1976, hlm. 2; "Hak Asasi Dilarang”, Tempo, 1 Desember 1977, Th VII, No. 42, hlm. 17. 
Baru juga sangat mendukung perkembangan musik dangdut dan secara langsung akan berdampak pada pola hubungan antara musik dangdut dan pemerintah. Salah satu contoh pejabat tersebut adalah Basofi Sudirman, mantan wakil gubernur Jakarta yang pada tahun 1992 melakukan rekaman lagu dangdut dengan judul "Tidak Semua laki-laki”. ${ }^{5}$ Lagu tersebut ternyata laris di pasaran. Basofi mengaku bahwa honor yang diperoleh dari lagu tersebut sekitar 400-500 juta. Namun demikian, ia mengaku bahwa honor tersebut seluruhnya ia sumbangkan untuk kegiatan sosial.

Terkait dengan kegemaran Basofi tersebut, Soeharto memberikan komentar yang sangat menarik, yang juga mencerminkan bagaimana pandangan pribadinya pada waktu itu terhadap musik dangdut. Berikut pernyataan komentarnya yang dikutip Tempo, 22 September 1992:

"Rakyatmu suka dangdut, pemudamu juga suka dangdut. Jadi, ya pantas saja kalau kamu juga nyanyi dangdut."

Komentar yang dilontarkan Soeharto terhadap Basofi tersebut merupakan sebuah "lampu hijau" dan sekaligus mencerminkan hubungan musik dangdut dan rezim Orde Baru yang begitu baik ketika itu. Dengan adanya komenter tersebut, Basofi mengaku bahwa dirinya merasa lega, sebab menurutnya secara tidak langsung komentar ini mengindikasikan restu Soeharto terhadap pejabat negara untuk berdangdut. Majalah Gatra pada 24 Februari 1996 melaporkan bahwa Basofi sendiri mengakui kapasitas politis musik dangdut sebagai sarana untuk menggalang dukungan dari penggemar genre musik tersebut.

Memasuki tahun 1994, dukungan rezim Orde Baru terhadap musik dangdut terlihat semakin jelas. Salah satu peristiwa yang paling menonjol adalah ketika Eddy Sud, salah satu anggota Tim Asistensi DPP Golkar di Bidang Seni Budaya, diundang dalam Festival Lagu Pop Internasional di Chile pada Februari 1994. Acara ini sebenarnya mengkhususkan diri pada lagu-lagu pop saja, namun Eddy Sud justru mengirimkan musisi-musisi dangdut, sayangnya penulis tidak menemukan sumber terkait siapa yang dikirim terserbut. Terkait dengan hal tersebut, Eddy mengatakan bahwa "pop itu bukan lagu Indonesia, tapi aslinya milik Amerika, sementara musik milik Indonesia adalah dangdut, sehingga apa yang menjadi milik kita, itu yang harus kita tonjolkan".

Selanjutnya, tahun 1995 dukungan rezim Orde Baru terhadap

5) Di laporkan dalam "Nama dan Peristiwa", Kompas, 22 April 1992, hlm. 14; KS, Theodore, "Lagu Dangdut Semakin Mendominasi Pasar", Kompas, Minggu 26 April 1992, hlm. 6. Selain itu, pejabat-pejabat tinggi lainnya seperti Kapolri Jendral (pol.) Drs. Kunarto dan Kapolda Metro Jaya Mayjen (pol.) Drs. M.H Ritonggo dalam sebuah acara hiburan yang diadakan di Wisma Bhayangkari pada 20 Juli 1992, juga tidak segan-segan bergoyang sambil menyanyikan lagu dangdut, lihat "Kapolri - Kapolda - Berjoget Bersama", Kompas, Rabu 22 Juli 1992, hlm. 7. 
perkembangan musik dangdut tampaknya mencapai puncaknya. ${ }^{6} \mathrm{Hal}$ tersebut sangat tampak sekali ketika peringatan 50 tahun kemerdekaan RI yang mengangkat tema "Semarak Dangdut 50 Tahun Indonesia Emas" pada bulan Agustus 1995. Acara tersebut dimeriahkan oleh Rhoma dan Elvie, serta 29 penyanyi dangdut papan atas lainnya, seperti A. Rafiq, Iis Dahlia, Itje Trisnawati, Lilis Carlina, Cucu Cahyati, Evie Tamala, Rita Sugiarto, Masyur S., Fahmi Sahab dan lain sebagainya. Penyisipan nama dangdut dalam peringatan nasional semacam itu jelas memperlihatkan peranan negara memajukan musik dangdut, sekaligus dukungan pemerintah terhadap wacana menjadikan dangdut sebagai musik nasional Indonesia. ${ }^{7}$

Moerdiono sendiri ketika membuka acara tersebut memberikan pernyataan yang secara jelas menunjukkan kegemaran dan dukungannya terhadap kemajuan musik dangdut. ${ }^{8}$ Cacuk Sudarijanto, selaku direktur pelaksana panitia HUT RI ke-50, mengatakan bahwa peringatan tersebut secara khusus menampilkan keberadaan musik dangdut yang merupakan wajah dan budaya khas Indonesia. Cacuk menambahkan bahwa peringatan hari ulang tahun Indonesia tersebut merupakan forum sosialisasi dan apresiasi terhadap musik dangdut yang bernilai historis dan monumental.

Peringatan HUT RI yang ke-50 dengan melibatkan musik dangdut berhasil dengan gilang-gemilang. Salah satu indikator keberhasilan ini adalah tingginya antusias masyarakat untuk menyaksikan acara tersebut. ${ }^{9}$ Selain itu,

6) Lono Lastoro Simatupang, Kaprodi Seni Pertunjukkan Universitas Gadjah Mada, mengatakan bahwa peringatan kemerdekaan Indonesia yang ke-50 dengan tema "Semarak Dangdut 50 Tahun Indonesia Emas", merupakan bentuk dukungan pemerintah yang sangat berarti bagi perkembangan musik dangdut. Menurutnya acara tersebut diselenggarakan dengan sangat mewah dan disponsori oleh negara. Wawancara Lono Lastoro Simatupang, 26 Agustus 2014, UGM.

7) Sebagaimana yang dikatakan oleh beberapa sumber bahwa efek dari dukungan rezim Orde Baru semacam itu adalah munculnya suatu identitas baru bagi Indonesiadangdut is Indonesian music. Beberapa sumber yang memaparkan hal ini misalnya "Dangdut, 'Lokal Genius' ke-4”,Kompas, Minggu 5 Mei 1991, hlm. 6; Elik Susanto, “Dangdut: Musik Teladan atau Setan”, Republika 13 Januari 1996.

8) Ketika itu Moerdiono mengatakan "dangdut itu sangat...sangat....sangat Indonesia". Ia sendiri mengaku bahwa ia sangat menyukai musik dangdut karena musik tersebut bersifat sederhana, gampang dimengerti oleh semua orang, bahkan ia menyebut dirinya sebagai rajanya raja dangdut. Pernyataannya ini dilaporkan dalam "Moerdiono Ternyata Penikmat Dangdut”, Kompas, Kamis 13 Juli 1995, hlm. 20. Besarnya peran Moerdiono dalam memajukan musik dangdut juga diakui oleh Ndang Zulfikar, pendiri Soneta Fans Club Indonesia (SFCI). Ia menyebut bahwa Moerdiono berperan dalam mengangkat derajat musik dangdut. Panggung Semarak 50 Tahun Indonesia Emas merupakan panggung terbesar dalam sejarah pertunjukkan live show Indonesia, bahkan panggungnya tercatat dalam MURI (Museum Rekor Indonesia) sebagai panggung terbesar. Wawancara Ndang Zulfikar, 30 Januari 2015, Jakarta.

9) Peringatan Semarak Dangdut 50 Tahun Indonesia Emas dihadiri sekitar 250.000300.000 orang. Jumlah tersebut jauh melampaui kapasitas bekas lapangan sirkuit Ancol yang berkapasitas hanya 120.000 orang. Lihat "Berkat Musik Dangdut Pekik Merdeka Disambut 300.000 Orang”, Kompas, Selasa 8 Agustus 1995, hlm. 4. 
peringatan HUT RI tersebut diliput langsung oleh beberapa stasiun televisi TPI, SCTV dan TVRI. Pagelaran ini disiarkan pula ke 53 negara melalui jaringan Star TV. Kita dapat membayangkan bahwa penyiaran dangdut ke 53 negara tersebut merupakan sebuah "promosi gratis" bagi musik dan musisi dangdut yang tampil dalam acara tersebut. Dengan demikian, acara ini jelas akan semakin membentuk citra dangdut sebagai musik khas Indonesia di mata dunia internasional.

Pada 23 Desember 1995, dilaksanakan acara "Gong 50 Tahun Indonesia Merdeka", yaitu sebuah acara yang menandai puncak dari Lomba Cipta Lagu Dangdut Bernafaskan Pancasila. Acara ini diselenggarakan oleh Badan Pembina Pendidikan Pelaksanaan Pedoman Penghayatan dan Pengamalan Pancasila (BP7) Pusat yang bekerjasama dengan Yayasan Kasih Abadi. Penggunaan kata Pancasila-sebagai satu-satunya azas yang boleh dianut oleh semua orang yang aktif berpolitik kala itu-di dalam acara semacam ini jelas memperlihatkan hubungan antara rezim Orde Baru dan musik dangdut yang sangat baik dan bagaimana pengasosiasian dangdut sebagai musik nasional Indonesia oleh rezim.

Pada perkembangannya, dukungan pemerintah Orde Baru terhadap perkembangan musik dangdut tidak hanya dilakukan melalui TVRI saja, tetapi juga melalui TPI (Televisi Pendidikan Indonesia). TPI menjadi salah satu stasiun televisi yang sangat menonjol dalam mendukung perkembangan musik dangdut. Hal semacam ini-selain tentu saja karena itung-itungan materi-tidak lepas dari fakta bahwa kepemilikan stasiun televisi ini berada di tangan putri Soeharto, Mbak Tutut (Faruk dan Afrinus Salam, 2003: 3016). Pengumuman yang dimuat Kompas pada 31 Desember 1995 berikut memperlihatkan bagaimana tingginya perhatian TPI terhadap musik dangdut:

"Pemirsa di kawasan jabotabek yang kurang puas menyaksikan pagelaran dangdut Gemilang 96 di layar kaca Televisi Pendidikan Indonesia (TPI), diundang untuk hadir langsung dan bergoyang bersama di kantor TPI, Pintu II Taman Mini Indonesia Indah Pondok Gede Jakarta Timur. Acara yang meriah ini akan mengetengahkan penyanyi dangdut papan atas seperti Camelia Malik, Rhoma Irama, Itje Trisnawati, Vetty Vera, Hamdan ATT, Cucu Cahyati, Lilis Karlina, dan sejumlah penyanyi lainnya. Acara akan diadakan Minggu 31 Desember 1995, mulai 23.30 WIB sampai dengan 1 Januari 1996, pukul 01.30 WIB”.

Tingginya perhatian TPI terhadap musik dangdut juga terlihat ketika diadakan acara Anugrah Dangdut TPI 1997. Meski acara itu sendiri sebenarnya sudah memperlihatkan hal tersebut, dukungan dari pemerintahan diperlihatan melalui keterlibatan serta pidato yang dibawakan Menteri Penerangan R. Hartono. Dalam pidato pembukaannya, R Hartono 
mengatakan bahwa musik dangdut akan menjadi musik kebanggaan bangsa Indonesia dan dapat memperkukuh persatuan dan kesatuan bangsa. ${ }^{10}$

Pewacanaan untuk menjadikan dangdut sebagai musik nasional Indonesia, selain ditempuh dengan memberikan dukungan terhadap perkembangan musik dangdut, juga ditempuh dengan pelarangan penyiaran musik dangdut yang ditampilkan secara seronok (kurang sopan) baik dari sisi tampilan maupun liriknya. Hal ini dapat dimengerti, mengingat Orde Baru menginginkan musik yang baik sebagai representasi ke-Indonesiia-an itu sendiri.

Salah satu lagu dangdut yang dilarang penayangannya di TVRI pada 1992 adalah "Jagung Bakar" di mana liriknya dianggap mengarah ke pornografi. Demikian juga halnya dengan lagu "Gadis atau Janda" yang dinyanyikan oleh Elvy Sukaesih dan Mansyur S. ${ }^{11}$ Sementara itu, ketika karir Elvy mendapatkan hambatan di dalam negeri, di tahun yang sama (1992), Elvy justru ditetapkan oleh salah satu majalah musik Jepang, Music Magazine, sebagai The Best Tokyo Live Show.

Selanjutnya muncul pertanyaan besar, setelah porses pewacanaan dangdut sebagai musik nasional Indonesia yang mengakibatkan semakin identiknya dangdut dengan entitas ke-Indonesia-an, apa yang didapatkan oleh rezim sebagai timbal baliknya? Pewacanaan untuk menjadikan dangdut sebagai musik nasional Indonesia, rasanya tidak akan mungkin terjadi apabila tidak ada keuntungan atau timbal balik yang didapat rezim Orde Baru atas "peng-Orde Baru-annya" tersebut. Paragraf di bawah ini akan mencoba menjawab pertanyaan tersebut.

Dilihat dari sisi ekonomi, sumbangan musik dangdut terhadap keuangan rezim Orde Baru sangat besar. Sebelum tahun 1992, pemerintah menetapkan pajak Rp 100 untuk setiap kaset yang terjual. Jumlah itu kemudian dinaikkan menjadi Rp 200 untuk setiap kasetnya sejak tahun 1992. Salah satu dari puluhan musisi dangdut yang rata-rata kasetnya terjual laris manis seperti halnya Itje Trisnawati, mampu menjual 1 juta kaset di tahun 1989 melalui lagunya “Duh Engkang” ciptaan Muhtar B.

Dari lagu Itje saja pajak yang diperoleh pemerintah adalah sebesar Rp $100 \times 1.000 .000=$ Rp 100 juta $^{12}$ (kurang lebih 1 Milyar untuk uang sekarang),

10) Dalam acara Anugerah Dangdut TPI 1997 ini, berbagai penobatan diberikan kepada sejumlah tokoh, dari politisi Golkar sampai musisi dangdut. Moerdiono dinobatkan sebagai Tokoh Dangdut 1997, di samping Rhoma Irama sebagai Penyanyi Legenda Dangdut 1997. Lihat "Moerdiono Tokoh Dangdut 1997, Iis Dahlia dan Meggy Z. Penyanyi Dangdut Terbaik”, Kompas, Jumat 11 Juli 1997.

11) Redana menyebut kemunculan lirik-lirik yang dipandang Orde Baru sebagai lagulagu yang mengarah pada pornografi, ditambah dengan tampilan musisinya yang bisanya sangat seksi, sebagai fenomena kebudayaan industri yang hanya berdasarkan untung rugi secara materi, lihat Bre Redana, "Kebudayaan, Dangdut, Paha", Kompas, Minggu 4 April 1993, hlm. 10.

12) Sayangnya penulis tidak menemukan sumber terperinci terkait berapa besar total 
terlepas dari apakah uang tersebut masuk ke kas negara atau masuk ke kantong oknum tertentu. Perlu diingat bahwa itu hanya dari satu lagu saja dari seorang Itje. Demikian juga halnya dengan penyanyi seperti A. Rafiq, Elvy Sukaesih dan Rhoma, semua tercatat pernah mencapai angka penjualan di atas 1 juta kaset. Besarnya pajak tersebut dan pemasukan yang diterima TVRI berupa biaya yang harus dikeluarkan oleh perusahaan rekaman setiap kali promosi di TVRI, di mana jumlahnya mencapai Rp 5.500 .000 per lagu untuk setiap kali promosi. ${ }^{13}$ Kita dapat membayangkan betapa besarnya penghasilan TVRI dari musik dangdut. Ditinjau dari sisi ekonomi alasan dukungan pemerintah Orde Baru terhadap pewacanaan musik dangdut sebagai musik nasional Indonesia menjadi cukup jelas.

Selanjutnya, pewacanaan untuk menjadikan dangdut sebagai musik nasional Indonesia ditinjau dari sisi politik juga terlihat membuahkan hasil bagi rezim Orde Baru. Pada tahun 1996, Rhoma Irama yang dianggap sebagai musisi dangdut yang bersebrangan dengan kepentingan politik Orde Baru, memutuskan untuk menjadi pendukung Golkar. Rhoma Irama mengaku bahwa ia memilih bergabung dengan Golkar semata karena Allah. Ketika penulis mewawancarai Rhoma pada 6 Februari 2015 dan menanyakan mengapa ia sudah tidak lagi menjadi juru kampanye PPP sejak 1983, ia menjawab bahwa semua partai sekarang (1983) sudah berasaskan Pancasila, sehingga semua partai sekarang sama saja. Apabila pada tahun 1977 Rhoma memutuskan untuk bergabung dengan PPP, hal itu karena Islamnya, maka keputusannya untuk bergabung dengan Golkar juga karena Islamnya. Ia menambahkan bahwa keputusan bergabung dengan Golkar bukanlah keputusan yang instan, namun merupakan sebuah proses perenungan puluhan tahun dan baru pada tahun 1996 hal tersebut dapat terealisasikan. Menurut Rhoma, bergabungnya ia menjadi Juru Kampanye Golkar pada 1996 karena keyakinannya bahwa Golkar ketika itu justru lebih Islami daripada PPP yang mengatasnamakan Islam. Ia menyebut salah satu buktinya adalah mudahnya diadakannya pengajian-pengajian waktu itu, serta dukungan pemerintah Orde Baru terhadap pembangunan masjid di berbagai daerah. Ia melanjutkan bahwa memperjuangkan Islam melalui Golkar sebagai partai yang berkuasa jauh lebih efektif.

Keputusan Rhoma untuk bergabung dengan Golkar pada 1996, secara formal didahului oleh dukungan umat Islam secara umum kepada rezim

pajak dari musik dangdut.

13) Salah satu fakta yang mendukung komersialisasi musik dangdut terdapat pada acara Album Minggu tanggal 29 Maret 1992 yang memutarkan lagu "Memori di Daun Pisang" (Junaidi) secara berulang-ulang, hal ini tercatat dalam laporan surat kabar "Sajian Musik di TVRI 92\% Dangdut”, Kompas, Selasa 31 Maret 1992, hlm. 4. Tiap satu lagu yang diputar satu kali membutuhkan biaya Rp 5.500.000. Apabila terdapat 20 lagu dangdut yang diputar, maka TVRI memperoleh uang sebesar Rp 100.000.000 per hari dan itu tahun 1992, di saat dolar AS masih sekitar Rp 2.000 
yang sedang berkuasa. ${ }^{14}$ Sejak akhir periode 80 -an hingga 90 -an, dukungan umat Islam sangat tampak sekali. Terlepas dari apapun alasan Rhoma yang bersifat rohani untuk mendukung Golkar, yang jelas sikap rezim terhadap musik dangdut pada periode 90-an memainkan peran yang sangat penting.

Sejak bergabungnya Rhoma Irama dengan Golkar pada 1996, lirik-lirik lagunya yang terkenal kritis, semakin halus, bahkan dapat dikatakan sebagai lagu yang berfungsi sebagai hiburan semata. Hal ini sangat wajar, mengingat pada periode ini Rhoma aktif menjadi sebagai Juru Kampanye Golkar dan menjadi anggota DPR melalui partai tersebut. Meskipun demikian, nasehatnasehat agama tetap ia lontarkan melalui lagu-lagunya, misalnya dalam lagu "Baca” (1995), "Stress" (1995), "Mirasantika" (1997) dan lain-lain.

Dukungan penyanyi dangdut terhadap Golkar dalam pemilu tidak hanya datang dari Rhoma Irama saja. Camelia Malik, penyanyi dangdut yang terkenal dengan goyang Jaipong-nya mengatakan pada sebuah wawancara Kompas, 13 Mei 1997, bahwa ia sudah aktif sebagai artis penghibur massa Golkar sejak tahun 1982. Ia menambahkan bahwa pilihannya jelas pada Golkar dan hal itu berlaku secara konsisten. Menurut Mia (panggilan akrab Camelia Malik), fungsi artis dangdut di panggung kampanye Golkar adalah sebagai daya tarik yang akan membuat sebanyak-banyaknya rakyat Indonesia-terutama yang menyaksikan pertunjukkannya-memilih Golkar pada saat pencoblosan.

Ike Nurjanah dan Evi Tamala, dua artis dangdut yang sedang naik daun pada pertengahan 90-an juga tidak ketinggalan menyemarakkan kampanye Golkar. Mereka mendampingi Ginanjar Kartasasmita, juru kampanye nasional Golkar sekaligus Menteri Negara Perencanaan Pembangunan Nasional/Ketua Bappenas, ketika berkampanye di Ciamis dan Tasikmalaya pada 6 Mei 1997. Akibat banyaknya penyanyi-penyanyi dangdut yang memenuhi panggung-panggung kampanye Golkar, Tempo pada edisi $27 \mathrm{Mei}$ 1997 menyebut dangdut sebagai “musik resmi” kampanye 1997.

Demikian juga halnya dengan kampanye Bambang Trihatmodjo (putra sulung Soeharto) pada tanggal yang sama di Lapangan PSPT juga didampingi artis dangdut super top yaitu Rhoma Irama dan Camelia Malik. Para penyanyi bertindak sebagai penghibur sekaligus juru kampanye, mengajak massa yang hadir untuk meningkatkan ukhuwah Islamiyah (persaudaraan sebagai sesama Muslim) dan meningkatkan solidaritas nasional tanpa memandang suku, ras, golongan dan asal-usul. Seperti biasa, setelah memberikan nasihatnya yang singkat, Rhoma Irama kemudian membawakan lagu “135.000.000” yang

14) Dukungan umat Islam terhadap Soeharto sebagai calon presiden dalam periode selanjutnya (1992-1997) ini jelas sekali sangat berpengaruh terhadap pilihan Rhoma untuk mendukung partai pemerintah pada pemilu 1997. Hal ini dikarenakan Rhoma Irama dengan terang-terangan seringkali meminta kalangan ulama untuk menegurnya apabila ia melakukan kesalahan dalam bermusik. Wawancara Ndang Zulfikar, Jakarta, 30 Januari 2015. 
serentak membuat massa yang hadir ikut bergoyang.

Secara singkat dapat dikatakan bahwa pewacanaan dangdut sebagai musik nasional Indonesia pada dekade 1990-an pada akhirnya mendatangkan keuntungan bagi kedua belah pihak (musisi dangdut dan rezim Orde Baru). Terlepas dari berbagai kepentingan yang ada di belakang proses pewacanaan tersebut, yang jelas hal tersebut memberikan dampak yang luar biasa terhadap perkembangan musik dangdut.

\section{Kesimpulan}

Berdasarkan tulisan di atas, maka dapat ditarik beberapa kesimpulan. Pertama, ternyata wacana yang digulirkan rezim Orde Baru untuk menjadikan dangdut sebagai musik nasional Indonesia tidak terlepas dari perkembangan musik dangdut yang sangat luar biasa dalam periode 1970an hingga 1990-an. Kedua, cara yang ditempuh oleh rezim Orde dalam mewacanakan dangdut sebagai musik nasional Indonesia pada pertengahan 1990-an diawali dengan pemberian dukungan terhadap perkembangan musik dangdut dan sejumlah pelarangan terhadap lagu-lagu dangdut yang dianggap memiliki unsur negatif, seperti pornografi. Dukungan yang diberikan rezim Orde Baru terhadap perkembangan musik dangdut berupa pernyataan maupun tindakan sejumlah pejabat tinggi rezim Orde Baru. Selain itu, cara yang ditempuh juga dengan melibatkan musisi-musisi dangdut dalam acara kenegaraan, seperti yang terjadi saat peringatan hari kemerdekaan Indonesia tahun 1995. TVRI juga memainkan peran yang besar terhadap upaya menumbuhkan wacana tersebut.

Ketiga, bergulirnya wacana untuk menjadikan dangdut sebagai musik nasional Indonesia pada dekade 90-an ternyata sangat menguntungkan baik bagi musisi dan musik dangdut maupun bagi rezim Orde Baru. Istilah musik dangdut akhirnya semakin lekat dengan entitas ke-Indonesia-an yang secara otomatis berdampak positif terhadap perkembangan musik dangdut. Demikian halnya dengan rezim Orde Baru, dari sisi ekonomi dan politik telah mendapatkan keuntungan yang luar biasa dengan digulirkannya pewacanaan tersebut.

\section{Referensi}

\section{Buku}

Faruk dan Afrinus Salam. Hanya Inul. Yogyakarta: Galang Offset, 2003.

Browne, Susan. The Gender Implications of Dangdut Kampungan: Indonesian 'Low Class' Popular Music. Clayton, Victoria: Monash Asia Institute, Monash University, 2000.

Syamsudin Haesy. Semarak Dangdut 50 Tahun Indonesia Emas. Jakarta: Pirus Interprise, 1995. 


\section{Surat Kabar, Majalah}

Akmal Nasery Basral dan BL, "Sebuah Goyang Bagi Integrasi" Gatra, 24 Februari 1996.

"Basofi Soedirman, Pak Harto Memberi Komentar", Tempo, No. 28, Tahun XXII, 22 September 1992.

“Berkat Musik Dangdut Pekik Merdeka Disambut 300.000 Orang”, Kompas, 8 Agustus 1995.

BreRedana, "Kebudayaan, Dangdut, Paha”, Kompas, 4 April 1993.

"Camelia Malik: Warna Saya Jelas”, Kompas, 13 Mei 1997.

"Dangdut dengan Kemasan Internasional", Kompas, 31 Desember 1991.

“Dangdut, 'Lokal Genius' ke-4”,Kompas, 5 Mei 1991.

“Dangdut Menepis Beban Sejarah”, Kompas, 5 Mei 1991.

"Dangdut Semakin Perkasa, Peluang Ekspor Mulai Terbuka", Kompas, 25 Februari 1990.

"Dua Halaman Doa untuk Bapak Presiden Muhammad Soeharto", Tempo, 9 Mei 1992.

"Elvy Sukaesih Gadis atau Janda”, Tempo, No. 52 Tahun XXI, 22 Februari 1992.

"Gebyar Dangdut Pancasila di TMII", Kompas, 19 Desember 1995.

"Hak Asasi Dilarang”, Tempo, 1 Desember 1977, Th VII, No. 42.

"Itje, Eddy Sud dan Eka", Kompas, 17 Desember 1989.

Jack Joetabarat "Sekitar Festival Lagu Populer ASEAN: Lagu dan Penyanyi Kita yang Memalukan”, Aktuil, No. 20 Tahun XIII, 3 Agustus 1981.

"Kapolri - Kapolda - Berjoget Bersama", Kompas, 22 Juli 1992.

"Ketua Umum DPP Golkar: Kampanye Momentum Penting”, Kompas, 7 Mei 1997.

“Kontroversi Musik Dangdut TVRI”, Kompas, 31 Oktober 1992.

KS, Theodore, "Lagu Dangdut Semakin Mendominasi Pasar", Kompas, 26 April 1992.

"Kontroversi Musik Dangdut di TVRI Membuat Camelia Malik dan Rhoma Irama Menghadap Direktur Televisi Aziz Husain”, Kompas, 15 November 1992.

"Kota Guangzhou Digoyang Dangdut”, Kompas, 6 November 1991.

"Lagu Rupiah akan Dilarang di Teve", Kompas, 21 September 1976.

"Moerdiono Ternyata Penikmat Dangdut", Kompas, 13 Juli 1995.

"Moerdiono Tokoh Dangdut 1997, Iis Dahlia dan Meggy Z. Penyanyi Dangdut Terbaik", Kompas, 11 Juli 1997.

"Musik Dangdut yang Tampil Seronok Dilarang Manggung”, Kompas, 27 September 1989.

"Musik Dangdut di Festival Internasional Chile”, Kompas, 10 Februari 1994.

"Nama dan Peristiwa", Kompas, 22 April 1992.

"Pak Moerdiono akan Tampil di Acara Pesta Rakyat Indonesia Emas", Kompas, 11 Agustus 1995.

“Panggung Dangdut TPI”, Kompas, 31 Desember 1995.

“Pasar Kaset Lesu, Agen Barat Dituding”, Kompas, 7 Juli 1991.

"PDI Soroti Orang Muda dan Pendidikan, Golkar Soal Kesejahteraan, PPP Atasi Kemiskinan”, Kompas, 29 April 1997.

“Penayangan Dangdut di TVRI Diperketat”, Kompas, 4 Februari 1992.

"Peredam Masa yang Bergejolak", Gatra, 24 Februari 1996.

"Reynold dan Camelia Malik ke Kuala Lumpur", Kompas, 7 Desember 1986.

"Rhoma Irama", Kompas, 6 September 1992. 
“Sajian Musik di TVRI 92\% Dangdut", Kompas, 31 Maret 1992.

"Semarak Dangdut 50 Tahun Indonsia Emas: Rhoma dan Elvie Tampil Bersama”, Kompas, 12 Juli 1995.

"Semarak Dangdut di Ancol Dimeriahkan 30 Penyanyi", Kompas, 5 Agustus 1995.

S.N. Ratmana, "Lagu-lagu Pop sebagai Saluran untuk Melihat Aspirasi Masyarakat:

Perlu Penyaringan, tapi juga Pendekatan Lapang Dada” Kompas, 12 Oktober 1976.

Elik Susanto, "Dangdut: Musik Teladan atau Setan”, Republika, 13 Januari 1996.

"The Day of the Dangduts", Tempo, No. 10 Thn. IX 5 Mei 1979.

"TVRI Menghentikan Sementara Penyiaran Paket Musik Safari”, Kompas, 11 Desember 1992.

\section{Internet}

"Saya Dibooking Pak Ginandjar", http:m.tempo.co/read/ news/1997/05/27/05577/55/saya-di-booking-pak-ginandjar. Diakses pada 19 Januari 2016.

\section{Sumber Lisan}

Rita Sugiarto, Penyanyi Dangdut, 3 Februari 2015.

Rhoma Irama, Penyanyi Dangdut, 6 Februari 2015. 